\title{
THE TREATMENT OF ASYMMETRIC JURISDICTION CLAUSES IN FINANCIAL CONTRACTS IN FRANCE AND ENGLAND
}

\author{
Tolek Petch ${ }^{*}$
}

\begin{abstract}
Recent case law demonstrates a significant difference in approach to the construction and validity of asymmetric jurisdiction clauses under the Brussels 1 bis regulation (Regulation 1215/2012), and its predecessors, by the courts in England and France. In this paper, the compatibility of such clauses with Article 25 of Regulation 1215/2012 is considered. The relevant case law of the French courts and the English courts is then analysed. The paper concludes that there are good commercial and legal reasons to uphold such clauses in a commercial context between parties of presumptively equal bargaining power. The doubts expressed by the French courts should therefore be set aside.
\end{abstract}

\section{A. INTRODUCTION}

This paper considers the approach taken to asymmetric or one-sided jurisdiction clauses by courts in France and England. Such clauses are very common in international commerce and reflect the need of a financing party to be able to pursue the borrower/debtor where his assets are located. It will also be argued that they comply with Article 25 of EU Regulation 1215/2012 (the Brussels 1 bis Regulation). The French courts have, on the other hand taken a different approach; in particular, the Cour de cassation has expressed difficulties with such clauses as they are seen as contrary to the principle of legal certainty that lies at the heart of the Brussels 1 bis Regulation. In this paper, I will argue that the French approach is mistaken and that such clauses ought to be given effect to in a commercial setting. Clearly, other considerations come to the fore if one is dealing with weaker parties who are specifically protected by the Brussels 1 bis Regulation (ie consumers, insureds, employees).

An example of such a clause is provided by the Loan Market Association standard documentation:

1. Enforcement

1.1 Jurisdiction

(a) The courts of England have exclusive jurisdiction to settle any dispute arising out of or in connection with this Agreement (including a dispute relating to the existence, validity or termination of this Agreement [or any non-contractual obligation arising out of or in connection with this Agreement]) (a 'Dispute').

\footnotetext{
* Associate, Slaughter and May, London.
} 


\section{The Treatment of Asymmetric Jurisdiction Clauses in Financial Contracts in France and England}

(b) The Parties agree that the courts of England are the most appropriate and convenient courts to settle Disputes and accordingly no Party will argue to the contrary. (c) This Clause 1.1 (Jurisdiction) is for the benefit of the Finance Parties only. As a result, no Finance Party shall be prevented from taking proceedings relating to a Dispute in any other courts with jurisdiction. To the extent allowed by law, the Finance Parties may take concurrent proceedings in any number of jurisdictions.

Such clauses have two characteristics. They are exclusive as regards the borrower who is required to sue the Finance Parties in England. However, the clause is non-exclusive as regards the Finance Parties who retain the right to sue in England or any other courts with jurisdiction. ${ }^{1}$ Asymmetric jurisdiction clauses are also common (but not universal) in bond transactions, securitisations and secured financing transactions.

\section{B. REQUIREMENTS OF ARTICLE 25 OF REGULATION 1215/2012}

Article 25(1)-(2) of Regulation 1215/2012 states:

1. If the parties, regardless of their domicile, have agreed that a court or the courts of a Member State are to have jurisdiction to settle any disputes which have arisen or which may arise in connection with a particular legal relationship, that court or those courts shall have jurisdiction, unless the agreement is null and void as to its substantive validity under the law of that Member State. Such jurisdiction shall be exclusive unless the parties have agreed otherwise. The agreement conferring jurisdiction shall be either: (a) in writing or evidenced in writing;

(b) in a form which accords with practices which the parties have established between themselves; or

(c) in international trade or commerce, in a form which accords with a usage of which the parties are or ought to have been aware and which in such trade or commerce is widely known to, and regularly observed by, parties to contracts of the type involved in the particular trade or commerce concerned.

2. Any communication by electronic means which provides a durable record of the agreement shall be equivalent to 'writing'.

Article 25 applies from 10 January 2015. Article 23 of Regulation 44/2001 was framed in similar terms, except that one of the parties had to be domiciled in a Member State. Where such an agreement was concluded by parties, none of whom was domiciled in a Member State,

\footnotetext{
${ }^{1}$ Richard Fentiman, 'Unilateral Jurisdiction Agreements in Europe' (2013) 72 Cambridge Law Journal 24.
} 
Article 23(3) provided that 'the courts of other Member States shall have no jurisdiction over their disputes unless the court or courts chosen have declined jurisdiction'. Article 23 applied from 1 March 2002.

Article 23 of the 2007 Lugano Convention is to the same effect as Article 23 of Regulation 44/2001 except the reference to a Member State is replaced by a State bound by the Convention. The Lugano Convention was concluded between the Member States of the European Union (except Denmark) and Denmark, Iceland, Norway, and Switzerland. However, Denmark became bound by Regulation 44/2001 from 1 July 2007 and became bound by Regulation 1215/2012 from 10 January 2015. It is clear that a number of requirements must be met in order for a jurisdiction clause to meet Article 25(1)-(2) of Regulation 1215/2012, Article 23 of Regulation 44/2001 and Article 23 of the Lugano Convention. It is not necessary to consider all of these requirements, and the associated case law of the European Court of Justice (ECJ), as this paper is confined to asymmetric jurisdiction clauses that are in writing or evidenced in writing'.

According to Article 25(1) (A) the parties, (B) regardless of their domicile, (C) have agreed (D) that a court or the courts of a Member State (E) are to have jurisdiction (F) to settle any disputes which have arisen or which may arise $(\mathrm{G})$ in connection with a particular legal relationship, $(\mathrm{H})$ that court or those courts shall have jurisdiction, (I) unless the agreement is null and void as to its substantive validity under the law of that Member State. It is instructive to examine whether an asymmetric jurisdictional clause satisfies each of the requirements of Article 25(1). As to (A) the typical jurisdiction clause referred to above applies to the parties to the agreement. Point (B) will always be satisfied. As to (C) it is a factual matter whether agreement has been reached, although unless one party disputes the agreement alleging, for example, fraud, misrepresentation, force or duress applicable to the jurisdiction clause in question (rather than the contract in general) then there will be an agreement between the parties on jurisdiction. This follows from the independent nature of the jurisdiction clause from the rest of the contract.

In respect of (D) the agreement involves a choice of the courts of a Member State as regards its exclusive limb as the debtor is obliged to sue the Finance Parties in England. As regards its non-exclusive limb the clause states that 'no Finance Party shall be prevented from taking proceedings relating to a Dispute in any other courts with jurisdiction'. This does not restrict the clause to proceedings taken before the courts of a Member State, but nor is it a submission to such other courts. According to the express words of the clause the other court 


\section{The Treatment of Asymmetric Jurisdiction Clauses in Financial Contracts in France and England}

must be 'with jurisdiction'. If proceedings are taken before a court in another Member State then the rules of jurisdiction in Regulation 1215/2012 will determine whether that court has jurisdiction. If proceedings are taken in Iceland, Norway, or Switzerland then jurisdiction will be governed by the Lugano Convention.

If proceedings are brought before a court that is not a Member State or a contracting state to the Lugano Convention (eg the US) then the question will be determined by the private international law of that state. It is only if the state where proceedings are ultimately brought has jurisdiction under its own conflict rules that the state in question is a state "with jurisdiction'. What the clause does not do is constitute a submission to the jurisdiction of all the courts in the world as otherwise the words 'with jurisdiction' would be otiose and deprived of legal effect. It is not therefore necessary to consider whether a clause that did expressly purport to constitute a submission to the exclusive jurisdiction of the courts of a Member State as regards one of the parties and to all other courts in the world as regards the other party is valid under Article 25(1) of Regulation 1215/2012.

Referring to point $(\mathrm{E})$, the agreement must confer jurisdiction. For the reasons given in the paragraph above, there is an express choice of the courts of England in any dispute between the debtor and the Finance Parties. As has been explained, there is no agreement by the debtor to submit to the jurisdiction of any other courts; there is simply a licence granted to the Finance Parties to sue the debtor in England or another court 'with jurisdiction'.

Point (G) requires that submission to jurisdiction applies to the 'particular legal relationship' concerned. In the case of the asymmetric jurisdiction clause referred to in section A above, the legal relationship is that created by the lending agreement. Whether the jurisdiction clause covers other claims will depend on its construction. However, for present purposes we are concerned with the core lending arrangement and not ancillary claims that might be brought which arguably fall outside the scope of the clause (eg claims for anticompetitive conduct). (H) specifies that that court shall have jurisdiction. Point (I) requires that the agreement on jurisdiction not be 'null and void as to its substantive validity under the law of that Member State', ie the chosen jurisdiction including its rules of private international law. ${ }^{2}$ For the reasons set out in section E, where the chosen jurisdiction is that of England there is no rule of English law or English private international law that impugns asymmetric jurisdiction clauses.

\footnotetext{
${ }^{2}$ Regulation (EU) No 1215/2012 of the European Parliament and of the Council of 12 December 2012 on jurisdiction and the recognition and enforcement of judgments in civil and commercial matters [2012] OJ L351/1 Recital (20).
} 


\section{CASE LAW OF THE ECJ}

Turning to the case law of the ECJ, the court has upheld clauses that allow the choice of the courts of more than one Member State. In Case 23/78 Meeth v Glacetal Sàrl, ${ }^{3}$ the agreement on jurisdiction provided for all actions against Meeth to be brought in Germany, where Meeth was domiciled, and all actions against Glacetal to be brought in France, where it was domiciled. In this case the choices were exclusive. However, it is clear from Regulations 44/2001 and $1215 / 2012$ that there is no requirement that the clause be exclusive as both regulations state that the jurisdiction 'shall be exclusive unless the parties have agreed otherwise'.

It follows that the non-exclusive choice of the courts of two Member States would be valid under the doctrine established in Meeth as applied under Regulations 44/2001 and 1215/2012. Logically, therefore, a clause that is exclusive as regards one party and nonexclusive as regards the other party should also be valid. Yet this is precisely the case with an asymmetric jurisdiction clause as the debtor is required to sue the Finance Parties in England (exclusive jurisdiction) whereas the Finance Parties may sue the debtor in England (nonexclusive jurisdiction) or other court 'with jurisdiction'.

The same conclusion follows from consideration of the Brussels Convention that applied prior to the entry into force of Regulation 44/2001. Article 17, third sub-paragraph, stated 'If the agreement conferring jurisdiction was concluded for the benefit of only one of the parties, that party shall retain the right to bring proceedings in any other court which has jurisdiction by virtue of this Convention'. The Brussels Convention clearly provided for the recognition of asymmetric jurisdiction clauses. The third sub-paragraph was not retained in Regulations 44/2001 or 1215/2012. However, there is nothing in the legislative history pertaining to either Regulation 44/2001 or 1215/2012 suggesting that there was an intention to change the law on this point as stated by the Brussels Convention. The most plausible explanation for the deletion of the third sub-paragraph is therefore not that there was an intention to change the law but that the point was regarded as sufficiently clear not to require restatement.

In Case 22/85 Anterist v Crédit Lyonnais ${ }^{4}$ the ECJ held that:

[s] ince Article 17 of the Convention embodies the principle of the parties' autonomy to determine the court or courts with jurisdiction, the third paragraph of that provision

\footnotetext{
${ }^{3}$ [1978] ECR 2133.

${ }^{4}$ [1986] ECR 1951.
} 


\section{The Treatment of Asymmetric Jurisdiction Clauses in Financial Contracts in France and England}

must be interpreted in such a way as to respect the parties' common intention when the contract was concluded. The common intention to confer an advantage on one of the parties must therefore be clear from the terms of the jurisdiction clause or from all the evidence to be found therein or from the circumstances in which the contract was concluded'. 5

It follows that:

[c]lauses which expressly state the name of the party for whose benefit they were agreed and those which, whilst specifying the courts in which either party may sue the other, give one of them a wider choice of courts must be regarded as clauses whose wording shows that they were agreed for the exclusive benefit of one of the parties. ${ }^{6}$

There is no suggestion in this jurisprudence that there are any further requirements that must be met where a jurisdiction clause is concluded for the benefit of one party only.

\section{CASE LAW OF THE COUR DE CASSATION}

In Mme X c Société Banque Privé Edmond de Rothschild ${ }^{7}$ (Rothschild) the Cour de cassation held that an asymmetric jurisdiction clause was wholly invalid. Mme $\mathrm{X}$ had opened a bank account with Banque Privé Edmond de Rothschild and alleged the mismanagement of her account by the bank. The clause in question stated:

[1]es relations entre la banque et le client sont soumises au droit luxembourgeois. Les litiges éventuels entre le client et la banque seront soumis à la juridiction exclusive des tribunaux de Luxembourg. La banque se réserve toutefois le droit d'agir au domicile du client ou devant tout autre tribunal compétent à défaut de l'élection de juridiction qui précède. $^{8}$

The intention of the clause is clear. The bank could only be sued by the client in the courts of its domicile, whereas the bank could sue the client either in the courts of her domicile or before any other court of competent jurisdiction. When sued before the French courts, the bank sought to rely on its exclusive right to be sued in Luxembourg.

The Cour de cassation held:

[m]ais attend qu'ayant relevé que la clause, aux termes de laquelle la banque se réservait le droit d'agir au domicile de Mme X ou devant 'tout autre tribunal compétent', ne liait,

\footnotetext{
5 ibid 1962.

6 ibid 1962-3.

7 [2013] Clunet 173 (note Brière).

8 Arrêt n 983 du 26 septembre 2012 (11-26.022) - Cour de cassation - Première chambre civile ECLI:FR:CCASS:2012:C100983.
} 
en réalité, que Mme X qui était seule tenue de saisir les tribunaux luxembourgeois, la cour d'appel en a exactement déduit qu'elle revêtait un caractère potestatif à l'égard de la banque, de sorte qu'elle était contraire à l'objet et à la finalité de la prorogation de compétence ouverte par l'article 23 du Règlement Bruxelles I. ${ }^{9}$

The jurisdiction clause was void in its entirety because of its 'caractère potestatif à l'égard de la banque'. There are a number of points that are unclear from the ruling. First, it is unclear why Mme X was not able, as a consumer, to rely on the specific protections under Regulation 44/2001. Article 16(1) enables a consumer to bring proceedings against the other party to the contract in the courts where the consumer is domiciled or the other party is domiciled. As she was suing the French subsidiary of the bank and the bank, the latter would be a necessary party to the French proceedings. ${ }^{10}$ Agreements on jurisdiction are only valid if entered into after the dispute has arisen, if they allow the consumer to bring proceedings in courts other than those indicated in Section 4 or if entered into by the consumer and the other party to the contract, both of whom are at the time of the conclusion domiciled or habitually resident in the same Member State, and which confers jurisdiction on the courts of that Member State. ${ }^{11}$ Mme X was not domiciled in Luxembourg, the clause did not confer any additional jurisdictional choice on her, and the agreement predated the dispute. The requirements for a valid choice of jurisdiction clause under the consumer contract provisions therefore do not appear to have been satisfied. We can only speculate why the consumer provisions were not relied on; perhaps because the bank had not pursued commercial or professional activities in France or by any means directed such activities into France. ${ }^{12}$

The decision could be interpreted as turning on Mme X's status as a consumer even if the requirements for consumer contracts in Article 15(1) of Regulation 44/2001 were not met. This interpretation of the decision was taken up by the tribunal d'arrondissement of Luxembourg in commercial judgments 127 and 128 of 2014 where the tribunal stated that:

c'est certainement l'idée que face à la banque la cliente devait être protégée contre une clause instaurant un déséquilibre entre les parties, de la même manière que la loi prohibe les clauses abusives dans les contrats conclus avec les consommateurs, qui a inspiré la decision'. 13

\footnotetext{
${ }^{9}$ ibid.

${ }^{10}$ Council Regulation (EC) No 44/2001 of 22 December 2000 on jurisdiction and the recognition and enforcement of judgments in civil and commercial matters [2001] OJ L012/1 Article 6.

11 ibid Article 17.

${ }^{12}$ As required by Article 15(1)(c) of Regulation 44/2001 (n 10).

${ }^{13}$ Commercial judgment $127 / 14$ and judgment 128/14, 17.
} 


\section{The Treatment of Asymmetric Jurisdiction Clauses in Financial Contracts in France and England}

The tribunal continued '[d]ans ce context il relève à juste titre qu'en l'espéce le litige met en presence des entités (association d'investisseurs et pool bancaire) qui ont un pouvoir de négociacion équivalent, de sorte qu'il échet de donner plein effet à l'autonomie de volenté des parties'. ${ }^{14}$

However, the reasoning of the Cour de cassation did not rely on the consumer or quasiconsumer nature of the case. The court's reasoning was based on the 'caractère potestatif' of the jurisdiction clause. Potestativité under French (and Luxembourg) law designates an obligation which is under the sole control of one of the contracting parties. According to Article 1174 of the Code Civil: '[t]oute obligation est nulle lorsqu'elle a été contractée sous une condition potestative de la part de celui qui s'oblige'. ${ }^{15}$ It follows that as a matter of French substantive law such obligations are null and void.

It is possible that the Cour de cassation applied the concept of potestativite as part of the law governing the substantive validity of the jurisdiction clause. In this case, the relevant law should have been that of Luxembourg and not France as the jurisdiction clause selected the exclusive jurisdiction of the Luxembourg courts. If the Cour de cassation intended this then as the Luxembourg Code civil contains a provision analogue to Article $1174^{16}$ the decision would be clear, albeit controversial in the light of the judgment of the ECJ in Benincasa $v$ Dentalkit Srl. ${ }^{17}$ In Benincasa the ECJ held in paragraph 29 that:

Article 17 of the Convention sets out to designate, clearly and precisely, a court in a Contracting State which is to have exclusive jurisdiction in accordance with the consensus formed between the parties, which is to be expressed in accordance with the strict requirements as to form laid down therein. The legal certainty which that provision seeks to secure could easily be jeopardized if one party to the contract could frustrate that rule of the Convention simply by claiming that the whole of the contract was void on grounds derived from the applicable substantive law.

The last interpretation of the judgment is that the concept of potestativite was seen as inherent in the Article 23 of Regulation 44/2001. This seems the best interpretation of the ruling that the clause 'revêtait un caractère potestatif à l'égard de la banque, de sorte qu'elle était contraire à l'objet et à la finalité de la prorogation de competence ouverte par l'article 23 du règlement de Bruxelles I' ${ }^{18}$ On this interpretation potestativité is contrary to the object and

\footnotetext{
14 ibid

${ }^{15}$ Code Civil, Livre III, Titre III, Chapitre IV, Section 1: Des obligations conditionnelles.

${ }^{16}$ Article 1174 Code civil luxembourgeois.

${ }^{17}$ Case C-269/95 [1997] ECR I-3767.

${ }^{18}$ Code Civil, Livre III, Titre III, Chapitre IV, Section 1: Des obligations conditionnelles.
} 
finality sought to be achieved by the Brussels 1 Regulation and therefore a rule of European law and not domestic French or Luxembourg law. Surprisingly, on this interpretation, the matter was regarded as acte claire as no question was referred to the ECJ. ${ }^{19}$

Further light was thrown on the matter by the subsequent decision of the Cour de cassation in Société Danne c Crédit Suisse ${ }^{20}$ (Crédit Suisse). Société Danne (Danne) had concluded two framework contracts with Crédit Suisse for loans. The framework agreements included a jurisdiction clause indicating that 'l'emprunteur reconnait que le for exclusif pour toute procédure est Zurich ou au lieu de la succursale de la banque où la relation est établie' while 'la banque est toutefois en droit d'ouvrir action contre l'emprunteur devant tout autre tribunal compétent'.

The cour d'appel d'Angers had upheld the validity of the clause. However this judgment was annulled by the Cour de cassation:

[a]ttendu que, pour accueillir l'exception d'incompétence soulevée par la société Crédit suisse sur le fondement de la clause attributive de juridiction, l'arrêt, après avoir rappelé que la société $\mathrm{ICH}$, laquelle faisait valoir que la rédaction de cette clause, dans un contrat d'adhésion, était particulièrement favorable à la banque, relève que le déséquilibre dénoncé, consubstantiel à une clause attributive de juridiction convenue entre deux contractants de pays différents, ne suffit pas à la rendre irrégulière au regard de la Convention de Lugano;

Qu'en se déterminant ainsi, sans rechercher si le déséquilibre dénoncé, en ce que la clause litigieuse réservait à la banque le droit d'agir contre l'emprunteur devant « tout autre tribunal compétent » et ne précisait pas sur quels éléments objectifs cette compétence alternative était fondée, n'était pas contraire à l'objectif de prévisibilité et de sécurité juridique poursuivi par le texte susvisé, la cour d'appel a privé sa décision de base légale ${ }^{21}$

The case is significant as there was no possibility of the consumer provisions applying to Danne, either expressly or by analogy. It follows that the interpretation of Mme X suggested above as depending on her status as a consumer or quasi-consumer cannot be retained. Moreover, the Cour de cassation did not rely on the substantive invalidity of the clause to hold it void. Nor was the concept of potestativité invoked as a reason for invalidating the clause.

\footnotetext{
${ }^{19}$ Gaudemet-Tallon considers it regrettable that a reference was not made to the ECJ: Hélène Gaudemet-Tallon, Compétence et exécution des jugements en Europe (5th edn, LGDJ 2015) 175.

${ }^{20}$ ECLI:FR:CCASS:2015:C100415; No de pourvoi: 13-27264.

21 ibid.
} 


\section{The Treatment of Asymmetric Jurisdiction Clauses in Financial Contracts in France and England}

The objection to the clause is to be found in the absence of predictability and legal certainty in that Crédit Suisse 'réservait [...] le droit d'agir contre l'emprunteur devant « tout autre tribunal compétent »'.22 It is unclear from the judgment if the Cour de cassation interpreted the clause as a submission by Danne to all the courts in the world or as a right of the bank to bring proceedings against Danne in all courts 'with jurisdiction'. As mentioned above, as a matter of English law the correct interpretation of the clause is the latter, although it is possible that the Cour de cassation interpreted the clause as having the former interpretation.

The final judgment of the Cour de cassation is Société eBizcuss.com c Apple ${ }^{23}$ (Apple). eBizcuss had entered into a distribution agreement with Apple Sales International to sell Apple products. eBizcuss subsequently alleged anti-competitive practices and unfair competition on the part of Apple Sales International, Apple Inc, and Apple Retail France, bringing proceedings in France before a tribunal de commerce.

The jurisdiction clause in issue stated:

[t]his Agreement and the corresponding relationship between the parties shall be governed by and construed in accordance with the laws of the Republic of Ireland and the parties shall submit to the jurisdiction of the courts of the Republic of Ireland. Apple reserves the right to institute proceedings against Reseller in the courts having jurisdiction in the place where Reseller has its seat or in any jurisdiction where a harm to Apple is occurring. ${ }^{24}$

eBizcuss argued that the clause 'présente un caractère potestatif à l'égard de ce dernier [Apple], contraire à l'objet et à la finalité de la prorogation de compétence ouverte par l'article $23 \mathrm{du}$ Règlement (CE) n 44/2001 du 22 décembre 2000'. This was rejected by the Cour de cassation: Mais attendu qu'ayant relevé que la clause d'élection de for imposait à la société eBizcuss d'agir devant les juridictions irlandaises tandis qu'était réservée à son cocontractant, de manière optionnelle, la faculté de saisir une autre juridiction, la cour d'appel en a exactement déduit que cette clause, qui permettait d'identifier les juridictions éventuellement amenées à se saisir d'un litige opposant les parties à l'occasion de l'exécution ou de l'interprétation du contrat, répondait à l'impératif de prévisibilité auquel doivent satisfaire les clauses d'élection de for; que le moyen n'est pas fondé sur ce point. ${ }^{25}$

\footnotetext{
22 ibid.

${ }^{23}$ ECLI:FR:CCASS:2015:C101053; No de pourvoi: 14-16898.

24 ibid.

25 ibid.
} 
The clause satisfied the requirements of predictability and legal certainty required by Regulation 44/2001 as the clause was exclusively in favour of the Irish courts as regards eBizcuss whereas Apple had the right to bring proceedings 'in the courts having jurisdiction in the place where Reseller has its seat or in any jurisdiction where a harm to Apple is occurring'. However, on the facts, the court held that the clause did not cover anti-competitive practices by Apple.

The difference between Danne and Apple lies in the fact that in the former Crédit Suisse reserved the right to institute proceedings 'devant « tout autre tribunal compétent »' whereas Apple was limited to suing in Ireland, the place where the reseller had its seat or where a harm to Apple was occurring.

It is curious that these two cases were decided differently as 'any jurisdiction where a harm to Apple is occurring' is not necessarily any more certain than 'tout autre tribunal compétent'. In both cases the proceedings may be brought inside or outside Member States of the European Union or contracting states to the Lugano Convention. Secondly, in both cases the court must have jurisdiction over the reseller and the subject matter of the dispute under its rules of private international law. Thirdly, it is not clear ex ante which court will have jurisdiction as in Apple the place where a harm is occurring cannot be determined in advance but only at the time of the eventual litigation. The same applies to a jurisdiction clause assigning 'tout autre tribunal compétent' as once a jurisdiction is invoked it will have jurisdiction, provided that it has jurisdiction over the parties under its own rules of private international law.

\section{E. CASE LAW OF THE ENGLISH COURTS}

It is well established that asymmetric jurisdiction clauses are valid under English law. It makes no difference if the clause is exclusive as regards one of the parties with a choice of arbitration for the other party or if it allows the other party to invoke any other court 'with jurisdiction'.

In NB Three Shipping Ltd v Harebell Shipping $L t d^{26}$ the Commercial Court upheld a complex jurisdiction and arbitration clause in a bareboat charterparty between Owners and Charterers. Clause 47 provided:

47.01 This Charterparty shall be governed by, and construed in accordance with, English law.

47.02 The courts of England shall have jurisdiction to settle any disputes which may arise out of or in connection with this Charterparty but the Owner shall have the option of bringing any dispute hereunder to arbitration.

${ }^{26}$ [2004] EWHC 2001 (Comm). 


\section{The Treatment of Asymmetric Jurisdiction Clauses in Financial Contracts in France and England}

In case of court proceedings the provisions of Clauses 47.03-47.09 (both inclusive) and of Clauses 47.11 and 47.12 shall apply, while in case of arbitration the provisions of Clauses 47.10-47.12 (both inclusive) shall apply.

47.03 The Owner may bring proceedings relating to this Charterparty in any other court which has jurisdiction by virtue of the Convention on jurisdiction and the enforcement of judgements in civil and commercial matters signed at Brussels on 27th September, 1968, as amended whether before the date of this Deed or not (the 'Brussels Convention').

47.04 Moreover, the Owner may bring any proceedings relating to this Charterparty: (a) in any court which has jurisdiction by virtue of any other convention or provision which is covered by article 57 of the Brussels convention; or

(b) in any court in a country or territory which is not at the relevant time a Contracting State under the Brussels Convention and in which property of the Charterer is then situated.

47.05 The Charterer waives any objection which it may have now or later (whether on the ground of forum non conveniens or otherwise) to any proceedings relating to this Charterparty being brought in the courts of England or in any court which is covered by Clause 47.03 or 47.04 .

47.06 The Charterer agrees that any process or other document connected with proceedings in the English courts which related to this Charterparty shall be treated for all purposes as having been duly served on it if received by Pannell Kerr Forster, New garden House, 78 Hatton Garden, London EC1N 8JA or by any other process agent appointed under the following subclauses.

47.07 Without the prior written consent of the Owner (which consent shall be granted on condition that the Charterer simultaneously appoints another process agent) the Charterer may not terminate the appointment of a process agent which has been appointed under this clause but, if such a process agent resigns or its appointment ceases to be effective, the Charterer within fourteen days thereafter shall appoint a new process agent.

47.08 A judgment relating to this Charterparty which is given or would be enforced by an English court shall be conclusive and binding on the Charterer and may be enforced without review in any other jurisdiction.

47.09 The Charterer shall have the same right to bring proceedings against the Owner in relation to the performance of its obligations hereunder, limited to bringing proceedings in the courts of England and the provisions of Clauses 47.07 and 47.08 apply equally mutatis mutandis to this clause as if they were set herein in full, changing 'Owner' to 'Charterer' and 'Charterer' to 'Owner' and, in relation thereto, the Owner hereby appoints WFW Legal Services Limited, presently of 15 Appold Street, London, EC2 as their process agent.

47.10 Any dispute arising from the provisions of this Charterparty or its performance which cannot be resolved by mutual agreement which the Owner determines to resolve by arbitration shall be referred to arbitration in London or, at Owner's option, in another city selected by the Owner by two arbitrators, one appointed by the Owners and one by the Charterers who shall reach their decision by applying English law. If the arbitrators so appointed shall not agree they shall appoint an umpire to make such decision.

47.11 Nothing in this clause shall exclude or limit any right which the Owner may have (whether under the law or any country, an international convention or otherwise) with regard to the bringing of proceedings, the service or process, the 
recognition or enforcement of a judgment or award or any similar or related matter in any jurisdiction.

47.12 In this clause 'judgment' includes order, injunction, declaration and any other decision or relief made or granted by a court.

Charterers believed they had been overcharged and that Owners had been making a secret profit. They accordingly instituted proceedings against Owners in the English court. Owners objected stating that they wanted the dispute referred to arbitration. It was argued by Charterers that once proceedings had been started by court action Owners lost the right to refer the dispute to arbitration. Morison $\mathrm{J}$ rejected that contention:

I cannot accept that argument because it seems to me to contradict the commercial sense of the clause as a whole. Clause 47 is designed to give 'better' rights to Owners than to Charterers. Thus, although Charterers are limited to action in the English Court, Owners are given the right to bring proceedings in any court which has jurisdiction by virtue of a Convention and Charterers waive objections on grounds of forum non conveniens; Charterers are required to provide a place for service within this jurisdiction whereas Owners are not; Charterers are constrained not to challenge enforcement of any judgment 'which is given or would be enforced by an English Court' whereas Owners are not. It seems to me that clause 47.02 gives Owners a right to stop or stay a court action brought against them, at their option. This gives the clause some practical effect and was designed to apply in circumstances such as these. If Charterers seek to bypass the Owners' determination to have disputes resolved by arbitration as contemplated by Clause 47.10, then Owners' option of bringing the disputes to arbitration remains, continuing Owners' control over the issue of arbitration or court. Charterers can obtain no advantage from 'jumping the starting gun'. Whilst I can see the force of the submission as to the words 'bringing any disputes' and the absence of the word 'refer'; it is, in my view putting too much weight on what is a point of semantics. The sense of the whole of Clause 47 is clear, I think. It seems to me that the option granted by clause 47.02 is not open ended. It would cease to be available if Owners took a step in the action or they otherwise led Charterers to believe on reasonable grounds that the option to stay would not be exercised. It would have been better had the precise circumstances in which the option could be exercised or lost were spelt out with greater clarity, but this failure does not, in my judgment render the clause unenforceable. In other cases referred to, the election or option has been properly circumscribed; here, Owners have 


\section{The Treatment of Asymmetric Jurisdiction Clauses in Financial Contracts in France and England}

given themselves in this Charterparty considerable latitude, consistent with what is,

largely, a one-sided clause. ${ }^{27}$

Accordingly a stay of Charterers' action was granted to enable the dispute to proceed to arbitration.

\section{In Law Debenture Trust Corporation PLC v Elektrim Finance BV, Elektrim SA and}

Concord Trust ${ }^{28}$ the claimant trustee sought to enforce the payment on moneys under bonds issued by Elektrim Finance and guaranteed by Elektrim SA following alleged events of default. Clause 29.1 of the trust deed stated that the deed was governed by English law. The remaining relevant provisions of Clause 29 are as follows:

29.2 Any dispute arising out of or in connection with these presents [...] may be submitted by any party to arbitration for final settlement under [the UNCITRAL Arbitration Rules], which rules are deemed to be incorporated by reference into this Clause 29.2.

29.3 The tribunal shall consist of three arbitrators. The Claimant party shall appoint one arbitrator. The Respondent party to the arbitration shall appoint one arbitrator [...] The Claimant party or parties and the Respondent party or parties to the arbitration shall jointly appoint the third arbitrator who shall be the chairman of the arbitral tribunal. The LCIA [...] shall act as the 'appointing authority' under the UNICITRAL Arbitral Rules in the event that:

(A) any party or parties to the arbitration fail to appoint an arbitrator;

or

(B) the parties to the arbitration fail to appoint jointly the third arbitrator within the time limits specified in the UNICITRAL Arbitration Rules.

29.4 The place of any such arbitration shall be London, and the language of the arbitration shall be English. The decision and award of the arbitrators shall be final and binding and shall be enforceable in any court of competent jurisdiction.

29.5 Save as provided in Clause 29.8 below, the parties exclude the jurisdiction of the courts under Section 45 and 69 of the Arbitration Act 1996.

29.6 The agreement by all the parties to refer all disputes arising out of or in connection with these presents [...] to arbitration in accordance with Clause 29.2 above is exclusive such that neither [ESA] nor [EFBV] shall be permitted to bring proceedings in any other court or tribunal other than by way of counterclaim in respect of proceedings brought by the Trustee and/or each of the Bondholders in respect of any of the above documents in such other court or tribunal in accordance with this Clause.

29.7 Notwithstanding Clause 29.2, for the exclusive benefit of the Trustee and each of the Bondholders, [EFBV] and [ESA] hereby agree that the Trustee and each of the Bondholders shall have the exclusive right, at their option, to apply to the courts of England, who shall have non-exclusive jurisdiction to settle any disputes which may arise out of or in connection with these presents [...] and that accordingly any suit, action or proceedings (together referred to as 'Proceedings') arising out of or in connection with any of the above may be brought in such courts.

\footnotetext{
27 ibid [11].

${ }^{28}$ [2005] EWHC 1412 (Ch).
} 
29.8 [EFBV] and [ESA] respectively:

(A) waive objection to the English courts on grounds of inconvenient forum or otherwise as regards Proceedings in connection with these presents [...]; and (B) agree that a judgement or order of an English court in connection with any of these presents [...] is conclusive and binding on them and may be enforced against them in the courts of any other jurisdiction.

29.9 Each of [EFBV] and [ESA] hereby appoints Law Debenture Corporate Services Limited at its offices for the time being at Fifth Floor, 100 Wood Street, London EC2V 7EX as its agent to receive service of process in any Proceedings in England based on these presents, [...]

Elektrim gave notice of arbitration challenging the events of default under Clause 29.2. Law Debenture challenged the arbitration preferring the dispute to be resolved by the courts. Elektrim contended that as the arbitral panel had been established there was an arbitration agreement to which Law Debenture was a party. Mann J. held that as Law Debenture had not participated in the arbitration it was entitled to rely on its right under Clause 29.7 to litigate:

Thus clause 29.7 has the effect of giving Law Debenture an option which the Elektrim parties do not have. They may litigate, but the Elektrim parties can be forced to arbitrate (unless litigation is started, in which case they can counterclaim). Law Debenture cannot be forced to arbitrate if it wishes to commence its own proceedings covering the same subject matter. I have difficulty in seeing any arguable limits, let alone any substantive limits, on the rights of Law Debenture in that respect. The one limit that probably exists is that Law Debenture cannot blow hot and cold, as Mr Glick accepted. If Law Debenture starts an arbitration it would have waived its right (or option) to go by way of litigation. By the same token, if it participates sufficiently in an arbitration, it may well be held to have waived its rights to exercise its option. Subject to that, it has its clear rights. ${ }^{29}$

Bank of New York Mellon v GV Films ${ }^{30}$ concerned an application for a stay by the defendant on the basis that there were proceedings before High Court of Madras in India. The dispute concerned two trust deeds governed by English law. Clause 25.2 provided:

The Courts of England are to have jurisdiction to settle any disputes which may arise out of or in connection with this Trust Deed or the Bonds and accordingly any legal action or proceedings arising out of or in connection with this Trust Deed or the Bonds ('Proceedings') may be brought in such courts. The Company irrevocably submits to the jurisdiction of such courts and waives any objections to Proceedings in such courts on

\footnotetext{
29 ibid [42].

${ }^{30}$ [2009] EWHC 2338 (Comm).
} 


\section{The Treatment of Asymmetric Jurisdiction Clauses in Financial Contracts in France and England}

the ground of venue or on the ground that the Proceedings have been brought in an inconvenient forum. This submission is for the benefit of the Trustee and each of the Bondholders and shall not limit the right of any of them to take Proceedings in any other court of competent jurisdiction nor shall the taking of Proceedings in any one or more jurisdictions preclude the taking of Proceedings in any other jurisdiction. ${ }^{31}$

The bank argued that there had been various events of default under the bonds. GV Films brought proceedings in the Madras High Court against the bank seeking a declaration that the notices of events of default were premature. Field $\mathbf{J}$ held that the jurisdiction clause was an exclusive jurisdiction clause in favour of the English courts as far as GV Films was concerned and there were no strong or sufficient reasons for not enforcing the clause against them. An anti-suit injunction followed restraining GV Films from continuing the Madras proceedings. It was not suggested by either party or the court that the jurisdiction clause was invalid on the basis that the clause provided that ' $[\mathrm{t}] \mathrm{his}$ submission is for the benefit of the Trustee and each of the Bondholders and shall not limit the right of any of them to take Proceedings in any other court of competent jurisdiction nor shall the taking of Proceedings in any one or more jurisdictions preclude the taking of Proceedings in any other jurisdiction' ${ }^{32}$

An asymmetric jurisdiction clause was again upheld by the High Court in Lornamead Acquisitions Limited $v$ Kaupthing Bank $H F{ }^{33}$ The relevant clause in a senior term and revolving facilities agreement was to the following effect:

(a) The courts of England have exclusive jurisdiction to settle any dispute arising out of or in connection with this Agreement (including a dispute regarding the existence, validity or termination of this Agreement) (a 'Dispute').

(b) The Parties agree that the courts of England are the most appropriate and convenient courts to settle Disputes and accordingly no Party will argue to the contrary.

(c) This clause 43.1 is for the benefit of the Finance Parties and Secured Parties only. As a result, no Finance Party or Secured Party shall be prevented from taking proceedings relating to a Dispute in any other courts with jurisdiction. To the extent allowed by law, the Finance Parties and Secured Parties may take concurrent proceedings in any number of jurisdictions.

Gloster $\mathbf{J}$ held that Kaupthing had no right to renounce the jurisdiction clause which satisfied the requirements of Article 17 of the Lugano Convention:

It does not entitle Kaupthing unilaterally to challenge proceedings previously brought

by Lornamead against Kaupthing in England in accordance with the terms of the

\footnotetext{
31 ibid [3].

32 ibid.

33 [2011] EWHC 2611 (Comm).
} 
English jurisdiction clause and in conformance with Lornamead's contractual obligation thereunder. Nor do the English jurisdiction clauses confer any such right. They make it clear that Kaupthing can take concurrent proceedings in other jurisdictions only 'to the extent permitted by law'. It was not disputed by Kaupthing, that if the English Court was indeed entitled to maintain jurisdiction, it was the Court first seised, and that accordingly it was no longer open to Kaupthing to bring proceedings against Lornamead in relation to the same cause of action in Iceland by virtue of Article $21 .^{34}$

Mauritius Commercial Bank Limited v Hestia Holdings Limited and Sujana Universal Industries Limited ${ }^{35}$ concerned an amended and restated agreement under the terms of which the parties agreed to change the governing law and jurisdiction from that of Mauritius to that of England. Clause 24(1) of the amended and restated agreement provided:

(a) The courts of England have exclusive jurisdiction to settle any dispute arising out of or in connection with this Agreement (including a dispute regarding the existence, validity or termination of this Agreement) (a 'Dispute').

(b) The Parties agree that the courts of England are the most appropriate and the most convenient courts to settle Disputes and accordingly no Party will agree [sic, obviously a typographical error for argue] to the contrary.

(c) This Clause 24.1 is for the benefit of the Lender only. As a result the Lender shall not be prevented from taking proceedings related to a Dispute in any other courts in any jurisdiction. To the extent allowed by law the Lender may take concurrent proceedings in any number of jurisdictions. 36

Popplewell $\mathrm{J}$ held the change in the governing law to be valid. The defendants argued that the jurisdiction clause was invalid as it conferred on the bank a power to sue the defendants in any court in the world. This argument was rejected by the judge:

It was contended on behalf of the Defendants that clause 24.1(c) confers a power on MCB to sue the lender and guarantor in any court in the world, rather than those courts which would otherwise regard themselves under their own rules of private international law as having competent jurisdiction. This is an erroneous reading of the clause. Subparagraph (c) merely provides that sub-paragraph (a) shall not prevent MCB from taking proceedings other than in England. It is not an agreement to confer jurisdiction on a foreign court where none would otherwise exist. It preserves MCB's right to sue in any court which would regard itself as of competent jurisdiction, notwithstanding

\footnotetext{
34 ibid [112].

35 [2013] EWHC 1328 (Comm).

36 Text in square brackets included in the original.
} 


\section{The Treatment of Asymmetric Jurisdiction Clauses in Financial Contracts in France and England}

what would otherwise have been the effect of clause 24.1(a), which, if it had stood alone, would have required MCB to sue in England.

I regard this as the natural construction of the sub-clause and the permissive language linking it to sub-clause (a) ('As a result the lender shall not be prevented...'). If there were any doubt, it would be necessary to keep in mind that it would be unlikely that the parties could have intended to submit their disputes to any court in the world however exorbitant. Indeed the Defendants' argument was that their construction, which bound them to litigation in any forum in the world of MCB's choosing, however inappropriate, was so unreasonable as to be invalid as contrary to English public policy. In the oft cited words of Lord Reid in Schuler:

'The fact that a particular construction leads to a very unreasonable result must be a relevant consideration. The more unreasonable the result the more unlikely it is that the parties can have intended it, and if they do intend it the more necessary it is that they shall make that intention abundantly clear., ${ }^{37}$

Popplewell $\mathrm{J}$ considered the decision of the Cour de cassation in Mme X c Société Banque Prive Edmond de Rothschild ${ }^{38}$ when discussing the defendants' argument that the agreement was governed by Mauritian law on the basis that the change to the governing law was invalid. Poppplewell J observed that ' $[\mathrm{t}]$ he decision is controversial and has been subjected to criticism by commentators, both domestically and in the context of Article 23 which requires an autonomous interpretation. It is arguably inconsistent with previous decisions of the Cour de cassation, although consistent with decisions of the lower courts. The Defendants' expert's opinion was that for these and a number of other reasons it was a matter of controversy and difficult to predict whether it would be applied in this case by a Mauritius court so as to treat clause 24.1 as invalid. His opinion was that the likelihood of it doing so was 50/50. MCB's expert, on the other hand, opined that he saw no compelling reason why the Mauritian courts would follow Rothschild.' ${ }^{39}$ The judge concluded that based on the evidence before the court there was a good arguable case that under Mauritian law Clause 24.1 would be treated as valid and effective notwithstanding the decision in Rothschild.

Finally, in Barclays Bank PLC v Ente Nazionale de Previdenza ed Assistenza dei Medici degli Odontoiatra ${ }^{40}$ the court considered a jurisdiction clause in a professional client agreement

\footnotetext{
${ }^{37}$ Schuler (L) AG v Wickman Machine Tool Sales Ltd [1974] AC 235 [37-8].

38 [2013] Clunet 173 (note Brière).

39 ibid [24].

${ }^{40}$ [2015] EWHC 2857 (Comm).
} 
(PCA). The PCA was governed by English law and the jurisdiction clause provided, so far as relevant:

[...] each of the parties irrevocably:

(a) agrees for [C's] benefit that the courts of England shall have jurisdiction to settle any suit, action or other proceedings relating to this Agreement ('Proceedings') and irrevocably submits to the jurisdiction of such courts (provided that this shall not prevent us from bringing an action in the courts of any other jurisdiction); and

(b) waives any objection which it may have at any time to the laying of venue of any Proceedings brought in any such court and agrees not to claim that such Proceedings have been brought in an inconvenient forum or that such court does not have jurisdiction over it.

Blair $\mathrm{J}$ stated 'As is frequently agreed for good practical reasons in financing transactions, it stipulates that exclusivity in favour of one court does not prevent the financing institution from bringing an action in the courts of any other jurisdiction'. ${ }^{41}$ However, as regards the client the clause was held to be an exclusive choice of the English courts:

There was a short debate in the skeleton arguments to whether such a clause can be regarded as 'exclusive'. The authority cited by Barclays was Continental Bank v Aeakos [1994] 1 WLR 588 at 594 C-F. Although not identical, the jurisdiction clause in that case (see p. $591 \mathrm{H}$ ) is structured similarly to that in the PCA. Barclays argues that though the clause does not expressly provide that it is 'exclusive', on its proper construction it is clear that it is exclusive as regards ENPAM.

I would accept this submission (for a contemporary discussion see Jurisdictional Choices in Times of Trouble, ed Georges Affaki and Horacio Grigera Naón, ICC, 2015, and see Mauritius Commercial Bank Ltd v Hestia Holdings Ltd [2013] EWHC 1328 (Comm)). ${ }^{42}$

Three principles can be drawn from the above cases. Firstly, it will be seen that on every occasion that the English courts have considered asymmetric jurisdiction clauses they have been given effect to. Secondly, the courts have rejected the submission that such clauses operate as a choice of the jurisdiction of all the courts in the world. ${ }^{43}$ Thirdly, such asymmetric clauses are regarded as being agreed for good practical reasons in financing transactions. ${ }^{44}$

\footnotetext{
41 ibid [124].

42 ibid [125-6].

${ }^{43}$ Mauritius Commercial Bank (n 17).

${ }^{44}$ Barclays Bank PLC (n 21).
} 


\section{The Treatment of Asymmetric Jurisdiction Clauses in Financial Contracts in France and England}

\section{F. COMMERCIAL REASONS FOR ASYMMETRIC JURISDICTION CLAUSES}

I now turn to discuss the commercial justification for the use of asymmetric jurisdiction clauses. As mentioned above this discussion is confined exclusively to agreements entered into between commercial parties. Accordingly it does not touch on the special rules provided by Regulation $1215 / 2012$ on jurisdiction in matters relating to insurance (Section 3), jurisdiction over consumer contracts (Section 4), and jurisdiction over individual contracts of employment (Section 5). Neither is national or EU law relating to the protection of consumers (including the Unfair Terms in Consumer Contracts Directive) considered here.

Such clauses are most common in financing transactions (see the LMA model jurisdiction clause cited above). The reason for their inclusion is simple. The bank wishes to be sued in a single jurisdiction (usually its place of incorporation or the location of the branch where the account is maintained). However, the bank requires flexibility in being able to pursue the borrower where its assets are. This will usually be the domicile of the borrower. However, if the borrower transfers its assets to a different jurisdiction then the bank needs to be able to sue the borrower where its assets are actually located.

It is not sufficient to rely on the enforceability of judgments as although this should not be an issue if the assets are located within a Member State of the European Union or a contracting state to the Lugano Convention, this is likely to be an issue if the assets are transferred elsewhere. Unlike arbitration agreements, where there is near universal recognition of foreign arbitral awards under the 1958 New York Convention, no parallel regime exists for court judgments which may be subject to a requirement of an international convention, or considerations of reciprocity, before a foreign judgment can be enforced.

It is the need to avoid the borrower diverting his assets to a jurisdiction other than the chosen one that provides the main justification and commercial use for asymmetric jurisdiction clauses. It is for this reason that such clauses often allow for the bringing of parallel proceedings. If a judgment of one court where the borrower's assets are located will not enforce a judgment against the borrower where other assets are located then the bank, to protect itself and recover the sums owing under the financing documents, may need to bring parallel proceedings.

There are, however, important safeguards to prevent the actions of the bank becoming vexatious or placing the debtor in an unfair position. Firstly, if all the assets are at the location of the borrower's domicile there will be no commercial reason for the bank to seek to bring proceedings elsewhere. Secondly, the chosen court must be 'with jurisdiction.' As held in 
Mauritius Commercial Bank, this requires the court before which the proceedings are brought to have jurisdiction under its own rules of private international law. If the dispute and the parties have no connection to that jurisdiction it is unlikely that the court would have jurisdiction to hear the case. Moreover, in the common law world the doctrines of forum non conveniens and lis alibi pendens are widely available to stay claims even if the court seised has jurisdiction if it is not an appropriate forum for the resolution of the dispute, or if parallel proceedings are being brought without an objective justification. In the case of the US there is an additional constitutional limitation on cases where the defendant does not satisfy 'minimum contacts' with the US. ${ }^{45}$ Thirdly, courts around the world have internal procedures to regulate proceedings and prevent oppressive and vexatious conduct, including, in the common law world, anti-suit injunctions.

Asymmetric jurisdiction clauses do not give rise to any more uncertainty than nonexclusive jurisdiction clauses that are expressly provided for under Regulation 44/2001 or Regulation 1215/2012. A non-exclusive jurisdiction clause offers a choice of forum which when seised will determine the dispute between the parties. However, where one of the parties chooses to seise another court that court will have to determine in accordance with its rules of private international law whether it has jurisdiction. To the extent that the judgments of the Cour de cassation have regard to legal certainty and predictability it is clear that an asymmetric jurisdiction clause is no different from a non-exclusive jurisdiction clause. In fact, it is a clause that is exclusive as regards one of the parties (usually, the debtor) and non-exclusive as regards the other party (usually, the finance party).

Although most common in financing transactions, asymmetric jurisdiction clauses are also common in debt capital market transactions (eg bond issues). The issuer of the bonds will agree to submit to the exclusive jurisdiction of the English courts. However, the clause typically goes on to provide that the submission 'is for the benefit of the Holders of the Instruments only. As a result, nothing in this Condition [...] shall prevent any Holder from taking proceedings relating to a Dispute ('Proceedings') in any other court with jurisdiction. To the extent allowed by law, Holders of Instruments may take concurrent Proceedings in any number of jurisdictions.' 46

\footnotetext{
${ }^{45}$ See eg International Shoe v Washington (1945) 326 US 310; Hanson v Denckla (1958) 357 US 235; Kulko v Superior Court (1978) 436 US 84; Helicopteros Nacionales de Columbia, SA v Hall (1984) 466 US 408; Goodyear Dunlop Tires Operations SA v Brown (2011) 564 US _ _; Daimler AG v Bauman (2014) 571 US

${ }^{46}$ Westpac Banking Corporation US\$ 70,000,000,000 Programme for the Issuance of Debt Instruments Offering Memorandum.
} 


\section{The Treatment of Asymmetric Jurisdiction Clauses in Financial Contracts in France and England}

The commercial sense behind such a clause is clear. The debtor submits to the exclusive jurisdiction of the English courts. However, if the debtor has dissipated or transferred its assets elsewhere then the Holders of the Instruments may bring proceedings in any court 'with jurisdiction' where the assets are located. As it is not possible to specify in advance where the assets may be transferred it is accordingly impossible to limit the Holders to a defined list of jurisdictions as this would be an invitation to the debtor to transfer assets to another jurisdiction which may not recognise a judgment from one of the chosen courts.

For the same reasons asymmetric jurisdiction clauses are encountered in securitisation transactions. The investors will want to be sued in a single jurisdiction which will typically be exclusive. However, the trustee for the noteholders will wish to have flexibility where there is a dissipation or transfer of assets by the issuer elsewhere.

The same applies to secured financing. In such cases 'the clause offers the lender the choice between bringing a claim at the place of business of the borrower, of the guarantor or at the location of the collateral, a choice that if it were equally to benefit the borrower, would carry no compelling justification. ${ }^{47}$

\section{G. CONCLUSION}

It is submitted that there are no compelling considerations that render such clauses uncommercial or unjustified in a contract negotiated between commercial parties. Of course, such clauses could be abusive in a consumer context, or in cases involving insurance contracts or individual employment contracts. It is for this reason that I have excluded them from the scope of this paper. However, where parties of presumptively equal bargaining power agree ${ }^{48}$ a clause that is exclusive as regards one of the parties and non-exclusive as regards the other there is no valid reason not to hold the parties to their agreement.

\footnotetext{
${ }^{47}$ Georges Affaki and Grigera Naón (eds), Jurisdictional Choices in Times of Trouble (ICC 2015) 8.

${ }^{48}$ Clearly, where there has been fraud of misrepresentation as to the jurisdiction clause itself then the party may not have agreed to the clause.
} 